\title{
Magnitude of excess carbon sequestration into the deep ocean and the possible role of TEP
}

\author{
W. Koeve* \\ Zentrum für marine Umweltwissenschaften (Marum), Fachbereich Geowissenschaften (FB5), Universität Bremen, \\ Postfach 330440, 28334 Bremen, Germany \\ Present address: Observatoire Midi Pyrénées (OMP), LEGOS, 14, av. Edouard-Belin, 31400 Toulouse, France
}

\begin{abstract}
It has been suggested that TEP (transparent exopolymer particles) may provide a vehicle for non-Redfield excess carbon export into the deep sea. Here, the hypothesis that organic carbon produced in excess of the Redfield C:N ratio is sequestered in the deep ocean is tested by a model-based mass balance approach. The model looks for a value of the C:N ratio of export production which is consistent with current knowledge of the rapid change of organic matter fluxes over depth, the remineralisation C:N ratio in the interior of the ocean, and the observed C:N ratios of sinking particles in the deep sea and at the sea floor. It is estimated that the contribution of excess carbon export into the deep ocean is equivalent to 3 to $5.6 \%$ (medians, depending on model assumptions; overall range: -16 to $21 \%$ ) of the conventional Redfield biological pump (C:N = 6.6). Elevated C:N ratios of sinking particles in the deep ocean of 9 to 23, and their increase with depth, can be explained by C:N ratios of export production being only slightly larger than the vertically integrated C:N ratio of remineralisation in the interior of the ocean. The basin scale effect of this preferential nitrogen remineralisation, within the seasonal thermocline, on carbon sequestration is 1 order of magnitude lower compared with Redfield equivalent remineralisation or $\mathrm{CaCO}_{3}$ sequestration. The often observed increase in the $\mathrm{C}: \mathrm{N}$ ratio of sinking particles with depth does not require that the remineralisation $\mathrm{C}: \mathrm{N}$ ratio increases with depth, but can also arise under conditions of constant $\mathrm{C}: \mathrm{N}$ remineralisation ratios. It is concluded that only a small fraction of carbon overconsumption in the surface ocean is sequestered into the deep ocean. The majority appears to be remineralised in the upper twilight zone.
\end{abstract}

KEY WORDS: Carbon flux $\cdot$ Net community production $\cdot \mathrm{C}: \mathrm{N}$ ratio $\cdot$ Redfield $\cdot$ TEP

\section{INTRODUCTION}

The biological pump effects a net flux of organic carbon produced at the ocean's surface into its interior. This flux sustains a vertical $\mathrm{CO}_{2}$ gradient, which contributes to the control of the mean state of the atmospheric $\mathrm{pCO}_{2}$ in the unperturbed climate system. Conventional understanding has been that fluxes of carbon are largely related to fluxes of the major plant limiting nutrients (nitrate and phosphate) in a tight ratio. This view was based on the observation that the elemental ratios of remineralisation of biogenic matter in the deep ocean and those of plankton particles in the sur- face ocean are both similar to each other and relatively constant (Redfield et al. 1963).

This constant-stoichiometry approach has been frequently challenged. In particular, evidence has accumulated that the $\mathrm{C}: \mathrm{N}$ ratio of net community production $(\mathrm{NCP}=$ gross primary production - community respiration) varies and is often higher than the Redfield $\mathrm{C}: \mathrm{N}$ ratio of 6.6. $\mathrm{NCP}_{\mathrm{C}: \mathrm{N}}$ ratios of up to 10 to 15 have been observed (Sambrotto et al. 1993, Körtzinger et al. 2001a). Biogenic net $\mathrm{CO}_{2}$-uptake in excess of the Redfield equivalent of nitrate-based new production has been referred to as carbon overconsumption (Toggweiler 1993). Mechanistically, carbon overconsump- 
tion can be related to the production and temporal accumulation of dissolved organic matter (DOM) low in nitrogen (Williams 1995, Kähler \& Koeve 2001) or the preferential remineralisation and re-use of nitrogen in the euphotic zone (Thomas et al. 1999, Anderson \& Pondaven 2001). Alternatively, unaccounted-for nitrogen sources $\left(\mathrm{N}_{2}\right.$-fixation, dissolved organic nitrogen) may falsely indicate excess uptake of carbon over Redfield equivalents of nitrogen uptake. Both $\mathrm{N}_{2}$-fixation and the use of remotely produced (Williams \& Follow 1998) dissolved organic nitrogen as nitrogen sources appear to be particularly important at low latitudes (Gruber \& Sarmiento 1997, Hansell et al. 2004).

Most important for the understanding of the oceanic carbon cycle, however, is whether and how this excess carbon uptake is linked to carbon fluxes into the deep ocean. Only the fraction of carbon which escapes remineralisation in the seasonally mixed layer and is sequestered into waters which are cut off from contact with the atmosphere on time scales of more than $1 \mathrm{yr}$ contributes to the surface to deep $\mathrm{CO}_{2}$ gradient (Riebesell \& Wolf-Gladrow 1992, Antia et al. 2001, Koeve 2002). At first glance, high $C: N$ ratios of new and export production are difficult to reconcile with $\mathrm{C}: \mathrm{N}$ ratios of remineralisation in the interior of the ocean, which largely conform with the Redfield ratio (Anderson \& Sarmiento 1994). This apparent discrepancy may be resolved if carbon is preferentially, that is even in excess of the already elevated $\mathrm{C}: \mathrm{N}$ ratio of export production, exported to the deep ocean or to the sea floor. The increase of the C:N ratio in sinking particles over depth (e.g. Martin et al. 1987, Honjo \& Manganini 1993, Conte et al. 2001) and elevated C:N ratios of freshly deposited detritus at the sea floor (Billet et al. 1983, Smith et al. 1998) may be quoted in support of this hypothesis.

Export production comprises the export of particulate and dissolved organic carbon, but only the seasonal DOM pool has been found to have an elevated C:N ratio (Williams 1995) and can, thereby, foster the export of excess carbon. However, the impact of DOM on long-term or deep carbon sequestration is restricted to regions of subduction of water masses, e.g. during thermocline ventilation (Doval \& Hansell 2000). It is only particles which can effect diapycnal transport, thus effectively linking the surface ocean and the deep sea. Bulk particulate organic matter (POM) in the surface ocean, however, has C:N ratios close to the Redfield ratio (Copin-Montégut \& Copin-Montégut 1983), as has marine snow (Alldredge 1998, A. Alldredge pers. comm.).

Recently, Engel \& Passow (2001) and Engel (2002) have proposed that TEP (transparent exopolymer particles, Alldredge et al. 1993) may provide a vehicle by which DOM from excess carbon uptake in the euphotic zone interacts with sinking particles and hence, contribute to particle export. TEP, which probably form from polysaccharides released by phytoplankton and bacteria, are very surface-active and easily coagulate among themselves and with other particles (Alldredge et al. 1993). In addition to this mechanistic importance for particulate carbon fluxes in the ocean (Boyd \& Stevens 2002, Passow 2002, 2004), it has been suggested that TEP, which have a high C:N ratio (Engel \& Passow 2001, Mari et al. 2001), may lead to a preferred export of carbon from the surface ocean (Engel \& Passow 2001). This process could provide a mechanism by which the total amount of carbon that is fixed in the ocean by phytoplankton and transported to the deep sea via the biological pump could well be more than calculated using the Redfield ratio (Engel 2002). Furthermore, a potential increase in TEP formation, resulting from rising $\mathrm{pCO}_{2}$ (Engel 2002), may function as a feedback mechanism, counteracting rising atmospheric $\mathrm{pCO}_{2}$ (Passow 2002), if it becomes sequestered into the deep ocean.

Testing this hypothesis is not straight forward, since our knowledge of upper ocean carbon and nitrogen export fluxes is very much limited by methodological problems of particle interceptor traps (Zeitzschel et al. 1978), which are most prominent in shallow to intermediate waters (Gardner 2000). Deep water particle flux data are believed to be more reliable since hydrodynamic as well as biological biases (trapping efficiency, swimmer artifacts) diminish. On average, deep ocean particle flux carbon to nitrogen ratios increase with depth by about $0.2 \pm 0.1$ units per $1000 \mathrm{~m}$ (Schneider et al. 2003), with average values of 7.9 to $8.2( \pm 0.5)$ at a depth of $4000 \mathrm{~m}$. Near the sea bed, sediment trap data as well as observations of freshly deposited phytodetritus at the sea floor show C:N ratios ranging up to 10 or even 20 (Smith et al. 1998, Lampitt et al. 2001, Beaulieu 2002). However, deep ocean C:N ratios of sinking organic matter do not provide direct information on the export or sequestration $\mathrm{C}: \mathrm{N}$ ratio. This is illustrated here with an example from laboratory-based batch (closed system) remineralisation experiments of non-axenic Chryptomonas sp. and Gymnodinium cultures (Verity et al. 2000). In both experiments, $\mathrm{POM}_{\mathrm{C}: \mathrm{N}}$ ratios increased over time, with maximum values of 14 to 24 (Fig. 1), though the initial

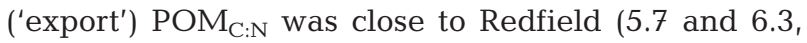
respectively). The explanation of the increase is that the C:N remineralisation ratios $\left(r_{\mathrm{C}: \mathrm{N}}\right.$, Fig. 1$)$, which are computed here from the time course change of POC and PON, were just a little lower (initially 4.8 and 5.6, respectively) than the $\mathrm{POM}_{\mathrm{C}: \mathrm{N}}$ at the beginning of the experiment. A little preferential N-remineralisation (Lee \& Cronin 1984, Wakeham et al. 1984) during the period of rapid organic matter decay gives rise to a 


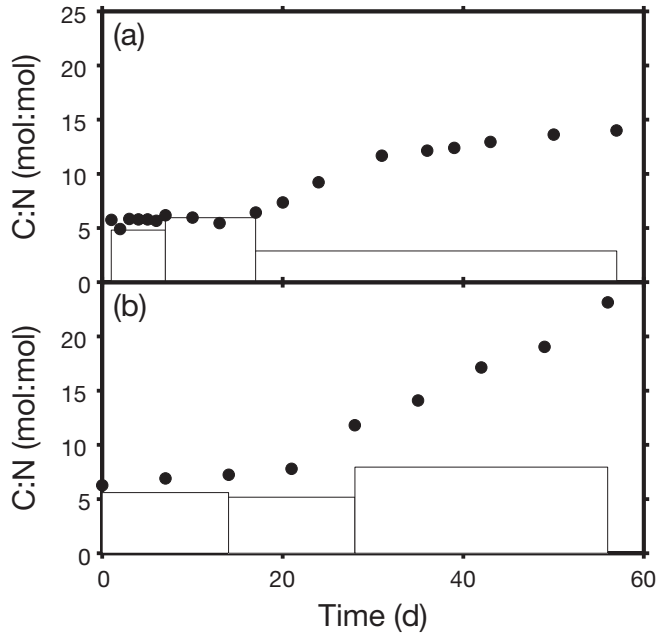

Fig. 1. $\mathrm{POM}_{\mathrm{C}: \mathrm{N}}(\bullet)$ and $r_{\mathrm{C}: \mathrm{N}}$ (bars) from 2 decomposition experiments of phytoplankton-derived POM (modified after Verity et al. 2000). (a) Cryptomonas sp. culture; (b) Gymnodinium sp. culture. Mean values of POM $_{\mathrm{C}: \mathrm{N}}$ (Verity et al. 2000) were converted to molar units, $r_{\mathrm{C}: \mathrm{N}}$ was computed from the time change of POC and PON data, which were provided by P. Verity (Skidaway Institute of Oceanography, USA; pers. comm.)

strong relative carbon accumulation in the residual POM towards the end of the experiment.

The hypothesis of this paper is that the magnitude and distribution of deep ocean C:N flux ratios $\left(J_{\mathrm{C}: \mathrm{N}}\right)$ can in a very similar way be explained by a small difference between initial C:N export ratios $\left(e_{\mathrm{C}: \mathrm{N}}\right)$ and the $r_{\mathrm{C}: \mathrm{N}}$ ratio in the water column, and hence are not an indication of significant excess carbon export into the deep ocean, for instance by means of TEP, or by other processes such as the stripping of 'old' (carbon-14 age) DOM from the water column by sinking particles (Druffel et al. 1996). In order to test this hypothesis, and considering the lack of reliable $J_{\mathrm{C}}$ and $J_{\mathrm{N}}$ data from the upper ocean, I chose to use a simple modelbased mass balance approach. The model basically looks for a value of the $\mathrm{C}: \mathrm{N}$ ratio of export production which is in agreement with our current knowledge of the rapid change of organic matter fluxes over depth, the remineralisation $\mathrm{C}: \mathrm{N}$ ratio in the interior of the ocean, and the observed $\mathrm{C}: \mathrm{N}$ ratios of sinking particles in the deep sea and at the sea floor. In the following section, I introduce the model and its basic assumptions. After presenting the results, I discuss the chosen parameters of the model in more detail against the background of our current understanding of flux and remineralisation of organic matter in the interior of the ocean. Finally, implications concerning the possible importance of TEP for excess carbon export and the coupling of surface new production and deep ocean fluxes are discussed.

\section{METHODS}

General outline. The 2 models used in this study apply the finding that the particle flux profile in the deep ocean can be described by a power-law function of export production due to particles $(E P)$ and depth $(Z)$ following Eq. (1) (equations are given in Table 1; for acronyms, see Table 2) (Martin et al. 1987), where $Z_{\mathrm{EP}}$ is the reference depth of export production, formally the depth of the euphotic zone, and $b$ is a vertical scaling parameter. This function, and similar power-law equa-

Table 1. Model equations. Analytical solutions (Eqs. 6, 7, 11 \& 12) are valid if $r_{\mathrm{C}: \mathrm{N}}$ is constant over depth. $R$ is integrated between $Z_{\mathrm{EP}}$ and $Z$. See Table 2 for definitions of parameters

$$
\begin{aligned}
& J_{(Z)}=E P \times\left(\frac{Z}{Z_{\mathrm{EP}}}\right)^{b} \\
& E P_{\mathrm{C}}=E P_{\mathrm{N}} \times e_{\mathrm{C}: \mathrm{N}}
\end{aligned}
$$

Model 1

$$
\begin{aligned}
J_{\mathrm{C}(Z)} & =e_{\mathrm{C}: \mathrm{N}} \times E P_{\mathrm{N}} \times\left(\frac{Z}{Z_{\mathrm{EP}}}\right)^{b_{\mathrm{C}}} \\
R_{\mathrm{C}(Z)} & =b \times e_{\mathrm{C}: \mathrm{N}} \times E P_{\mathrm{N}} \times Z^{b_{\mathrm{C}}-1} / Z_{\mathrm{EP}}^{b_{\mathrm{P}}} \\
R_{\mathrm{N}(Z)} & =\frac{R_{\mathrm{C}(Z)}}{r_{\mathrm{C}: \mathrm{N}}} \\
J_{\mathrm{N}(Z)} & =E P_{\mathrm{N}}-\int R_{\mathrm{N}(Z)} \times \mathrm{d} Z \\
& =E P_{\mathrm{N}} \times\left\{1-\frac{e_{\mathrm{C}: \mathrm{N}}}{r_{\mathrm{C}: \mathrm{N}}} \times\left[1-\left(\frac{Z}{Z_{\mathrm{EP}}}\right)^{b_{\mathrm{C}}}\right]\right\} \\
e_{\mathrm{C}: \mathrm{N}}^{\text {req }} & =\left[\left(\frac{Z}{Z_{\mathrm{EP}}}\right)^{b_{\mathrm{C}}} \times\left(\frac{1}{J_{\mathrm{C}: \mathrm{N}}}-\frac{1}{r_{\mathrm{C}: \mathrm{N}}}\right)+\frac{1}{r_{\mathrm{C}: \mathrm{N}}}\right]^{-1}
\end{aligned}
$$

Model 2

$$
\begin{aligned}
J_{\mathrm{N}(Z)} & =E P_{\mathrm{N}} \times\left(\frac{Z}{Z_{\mathrm{EP}}}\right)^{b_{\mathrm{N}}} \\
R_{\mathrm{N}(Z)} & =b \times E P_{\mathrm{N}} \times \frac{Z^{b_{\mathrm{N}}-1}}{Z_{\mathrm{EP}}^{b_{\mathrm{N}}}} \\
R_{\mathrm{C}(Z)} & =R_{\mathrm{N}(Z)} \times r_{\mathrm{C}: \mathrm{N}} \\
J_{\mathrm{C}(Z)} & =E P_{\mathrm{C}}-\int R_{\mathrm{C}(Z)} \times \mathrm{d} Z \\
& =E P_{\mathrm{N}} \times\left\{e_{\mathrm{C}: \mathrm{N}}-r_{\mathrm{C}: \mathrm{N}} \times\left[1-\left(\frac{Z}{Z_{\mathrm{EP}}}\right)^{b_{\mathrm{N}}}\right]\right\} \\
e_{\mathrm{C}: \mathrm{N}}^{\text {req }} & =J_{\mathrm{C}: \mathrm{N}} \times\left(\frac{Z}{Z_{\mathrm{EP}}}\right)^{b_{\mathrm{N}}}+r_{\mathrm{C}: \mathrm{N}} \times\left[1-\left(\frac{Z}{Z_{\mathrm{EP}}}\right)^{b_{\mathrm{N}}}\right]
\end{aligned}
$$


Table 2. Abbreviations and parameter values

\begin{tabular}{|llc|}
\hline Parameter & Remark & Standard value (range) \\
\hline$Z_{\mathrm{EP}}$ & Depth of the productive surface layer (euphotic zone) & $100 \mathrm{~m}$ \\
$E P_{\mathrm{N}}\left(E P_{\mathrm{C}}\right)$ & Export production of nitrogen (carbon) & $0.5 \mathrm{~mol} \mathrm{~m}^{-2} \mathrm{yr}^{-1}$ \\
$J_{\mathrm{N}(Z)}\left(J_{\mathrm{C}(Z)}\right)$ & Particle flux of nitrogen (carbon) at depth $Z$ & \\
$R_{\mathrm{N}(Z)}\left(R_{\mathrm{C}(Z)}\right)$ & Remineralisation of nitrogen (carbon) at depth $Z$ & $-0.68(-0.6$ to -1.3$)$ \\
$b$ & $Z$-exponent of the $J$ - $E P-Z$ curve (Eq. 1$)$ & $6.6(5.6 \text { to } 7.6)^{\mathrm{a}}$ \\
& $b_{\mathrm{N}}, b_{\mathrm{C}}$ are specific values for N and C & 5 to 15 \\
$r_{\mathrm{C}: \mathrm{N}}$ & $\mathrm{C}: \mathrm{N}$ ratio of remineralisation in the interior of the ocean & \\
$e_{\mathrm{C}: \mathrm{N}}{ }_{\text {req }}$ & $\mathrm{C}: \mathrm{N}$ ratio of export production & \\
$e_{\mathrm{C}: \mathrm{N}}$ & Value of $e_{\mathrm{C}: \mathrm{N}}$ required to sustain observed values of $J_{\mathrm{C}: \mathrm{N}}$ for & \\
$J_{\mathrm{C}: \mathrm{N}}$ & a given model and parameter set $\left(r_{\mathrm{C}: \mathrm{N},} b\right)$ & \\
${ }^{\mathrm{a} A l s o}$ experiments & \\
\hline
\end{tabular}

tions relating deep ocean fluxes with surface ocean primary production (Suess 1980, Betzer et al. 1984, Antia et al. 2001, Koeve 2002), reflect the dramatic decrease of organic particle flux over depth. The Martin-powerlaw empirical function has been successfully used to describe the vertical distribution of particle flux at a set of 17 open ocean stations for which depth-resolving flux observations were available (Berelson 2001). The regional range of $b$-values from Berelson (2001) guided the choice of the $b$-value range used in this paper. The Martin-power-law function, again with regionally variable $b$-values, is also in excellent agreement with the global 3-dimensional distribution of nutrients, total $\mathrm{CO}_{2}$ and oxygen (Schlitzer 2000, 2002).

Particle export into the deep ocean, as measured by particle interceptor traps, is mainly maintained by large fast sinking particles (Walsh \& Gardner 1992), which descend with sinking speeds in the order of 10 to $100 \mathrm{~m} \mathrm{~d}^{-1}$ towards the sea floor. Such marine snow particles are sites of intensive microbial activity (Smith et al. 1992, Ploug \& Grossart 2000), with turnover times of organic carbon due to respiration of only 8 to 9 d (Ploug et al. 1999). The Martin-curve type of power-law functions used in this study are assumed to integrate over a spectrum of particles with different sinking speeds and decay rates (Boyd \& Stevens 2002). Ocean flux data which are fitted into Martin-type curves are most credible in the deep ocean, where notorious problems of shallow traps, such as trapping efficiency (Buesseler 1991), contamination by swimmers (Karl \& Knauer 1989) and dissolution of particles during trap deployment (Kähler \& Bauerfeind 2001) vanish (Michaels et al. 1990, von Bodungen et al. 1991, Honjo et al. 1995, Scholten et al. 2001). Uncertainties in organic matter fluxes in more shallow depths are significant and, together with regional variations in the flux profile (Schlitzer 2000, 2002, Antia et al. 2001, Berelson 2001), reflected in this study by applying a rather large range of $b$-values (Table 2).
In the model, remineralisation of organic matter is computed from the change of organic matter flux over depth. Since the trapping efficiency of sediment traps varies with depth (Scholten et al. 2001, Yu et al. 2001), the ratio of carbon and nitrogen remineralisation and its possible change over depth cannot be assessed if only based on shallow trap data. This problem is most pronounced in the upper 500 to $1000 \mathrm{~m}$ of the ocean. As a substitute, the C:N ratio of remineralisation $\left(r_{\mathrm{C}: \mathrm{N}}\right)$ can be estimated from the distribution of the remineralisation products, in this case nitrate, total $\mathrm{CO}_{2}$ and oxygen, in the interior of the ocean. This approach looks at changes of these substances along wellchosen isopycnals or neutral surfaces (McDougall 1987) and includes corrections for isopycnal mixing of different end members (Takahashi et al. 1985), diapycnal mixing (Anderson \& Sarmiento 1994) and the time varying invasion of anthropogenic $\mathrm{CO}_{2}$ (Körtzinger et al. 2001b). By definition, remineralisation between the depth of the euphotic zone and the winter mixed layer cannot be estimated by this method, and it is assumed here that remineralisation ratios estimated from the permanent thermocline also apply to the seasonal thermocline. To reflect both regional and inter-study differences in $r_{\mathrm{C}: \mathrm{N}}$ and uncertainties of ratios within the seasonal thermocline, a range of $r_{\mathrm{C}: \mathrm{N}}$ values is applied (Table 2). This range is in good agreement with $r_{\mathrm{C}: \mathrm{N}}$ ratios estimated from decomposition experiments of phytoplankton-derived POM (Verity et al. 2000, Fig. 1).

The overall approach of this study was to estimate the value of the $\mathrm{C}: \mathrm{N}$ ratio of export production $\left(e_{\mathrm{C}: \mathrm{N}}\right)$ of particles which is required to sustain a given observed value of the C:N ratio of sinking particles $\left(J_{\mathrm{C}: \mathrm{N}}\right)$ in the deep ocean under the constraint of specified values for $b$ and $r_{\mathrm{C}: \mathrm{N}}$. This particular value of $e_{\mathrm{C}: \mathrm{N}}$ is referred to as $e_{\mathrm{C}: \mathrm{N}}^{\text {req }}$ hereinafter. I tested how $e_{\mathrm{C}: \mathrm{N}}{ }^{\text {req }}$ changes depending on the choice of deep ocean $J_{\mathrm{C}: \mathrm{N}}, b$ and $r_{\mathrm{C}: \mathrm{N}}$. The difference between $e_{\mathrm{C}: \mathrm{N}}{ }^{\text {req }}$ and the classical Redfield C:N ratio (6.6) is used as a measure of excess car- 
bon export and is reported as a percentage of the Redfield equivalent carbon flux. It is computed as excess = $\left(\mathrm{e}_{\mathrm{C}: \mathrm{N}}{ }^{\mathrm{req}}-6.6\right) / 6.6 \times 100$.

There is no explicit model domain for this study. The 1-dimensional model may be applied everywhere in the open ocean. Parameters, initial conditions and constraints from observations, however, are biased towards the Atlantic Ocean. Remineralisation C:N ratios from isopycnal analysis average over large horizontal distances, time scales of years and, close to their outcrop and ventilation regions, also over depth. In a similar way, $b$-values are usually computed for annual flux data and, hence, reflect the annually averaged decay of organic matter over depth and the observed range of deep ocean $J_{\mathrm{C:N}}$ (see 'Results') is used. Hence, this study intends to, and can only, look at the weighted average of excess carbon export into the deep ocean. There may be short periods, or specific regions, which are characterised by fluxes of $\mathrm{C}: \mathrm{N}$ ratios in excess of what is calculated here. For excess carbon export to be significant and, via TEP, to provide a possible feedback process compensating for increasing atmospheric $\mathrm{CO}_{2}$ concentrations (Passow 2002), however, it must also be visible in average calculations of this type.

Model details. Standard runs of both models are used to explore the overall response of the model system to elevated C:N ratios of export production of particles. For the $Z$-exponent of organic matter decay, I use a value of $b=-0.68$, which is the mean $Z$-exponent of particulate carbon flux estimated for the Atlantic Ocean by Antia et al. (2001), and $Z_{\mathrm{EP}}=100 \mathrm{~m}$. The model is initiated with a (particulate) nitrogen export production $\left(E P_{\mathrm{N}}\right)$ of $0.5 \mathrm{~mol} \mathrm{~N} \mathrm{~m} \mathrm{Nr}^{-1}$, which is a typical value for the temperate and subarctic North Atlantic (Koeve 2001). Carbon export production of particles $\left(E P_{\mathrm{C}}\right)$ is computed as $E P_{\mathrm{N}} \times e_{\mathrm{C}: \mathrm{N}}$, where $e_{\mathrm{C}: \mathrm{N}}$ is the $\mathrm{C}: \mathrm{N}$ ratio of export production. Model runs are carried out with values of $e_{\mathrm{C}: \mathrm{N}}$ ranging from 5 to 15 , reflecting the seasonal range of the $\mathrm{C}: \mathrm{N}$ ratio of $\mathrm{NCP}$, observed by Körtzinger et al. (2001a) in mesotrophic waters of the North Atlantic.

In Model 1, the carbon flux $\left(J_{\mathrm{C}}\right)$ profile is computed by applying the $J-E P-Z$ function (Table 1, Eq. 1 ) to values of $E P_{\mathrm{C}}$ computed for any given value of $e_{\mathrm{C}: \mathrm{N}}$. Carbon remineralisation $\left(R_{\mathrm{C}}\right)$ is deduced from the first derivative of the $J$-EP- $Z$ curve, and $R_{N}$, nitrogen remineralisation, is computed as $R_{\mathrm{N}}=R_{\mathrm{C}} / r_{\mathrm{C}: \mathrm{N}}$. The standard value of $r_{\mathrm{C}: \mathrm{N}}$ is set to 6.6. Finally, the nitrogen flux $\left(J_{N}\right)$ profile is estimated from the cumulative integral of $R_{\mathrm{N}}$ and $E P_{\mathrm{N}}$, and the resulting C:N ratio of particle flux is computed from $J_{\mathrm{C}: \mathrm{N}}=J_{\mathrm{C}} / J_{\mathrm{N}}$. Model 1 assumes that conventional methods for particulate organic carbon (POC) (Ehrhard \& Koeve 1999) measure the total amount of particulate organic carbon sampled with sediment traps and, hence, that estimates of the
$Z$-exponent $b$ include, for example, the contribution of TEP-associated carbon.

Model 2 reflects the possibility that TEP-associated carbon is only partly included in standard POC analysis (Passow \& Alldredge 1995, Engel \& Passow 2001, see also 'Discussion' 'Uncertainties of observed C:N flux ratios') of sinking particles. It only applies the $J$ $E P-Z$ function to the Redfield-associated carbon flux and treats any excess carbon flux independently of it. In fact, since the $\mathrm{C}: \mathrm{N}$ remineralisation ratio is always close to the Redfield value, this method largely preserves excess carbon during its transit to depth. Technically, this model computes the nitrogen flux $\left(J_{N}\right)$ profile from the $J-E P-Z$ profile and $E P_{\mathrm{N}}$ (Eq. 8) and estimates $R_{\mathrm{N}}$ from the first derivative of $J_{\mathrm{N}} \cdot R_{\mathrm{C}}$ is estimated from $R_{\mathrm{C}}=R_{\mathrm{N}} \times r_{\mathrm{C}: \mathrm{N}}$, and $J_{\mathrm{C}}$ is computed from integration of $R_{\mathrm{C}}$ over $Z$ and from $E P_{\mathrm{C}}$, which is estimated as above. Model equations, including analytical solutions for $r_{\mathrm{C}: \mathrm{N}}=$ constant, are given in Table 1 .

For both models, a series of sensitivity computations was performed using ranges of $e_{\mathrm{C}: \mathrm{N}}, r_{\mathrm{C}: \mathrm{N}}$ and $b$. For example, runs using constant $r_{\mathrm{C}: \mathrm{N}}$ values between 5.5 and 7.5 (for literature values see 'Discussion: C:N ratios of remineralisation in the interior of the ocean') are carried out, as well as experiments with depth variable $r_{\mathrm{C}: \mathrm{N}}$ values, computed from the function $r_{\mathrm{C}: \mathrm{N}}=6.2$ $\left(Z / Z_{\mathrm{EP}}\right)^{0.13}$, adopted from Martin et al. (1987) and a function $r_{\mathrm{C}: \mathrm{N}}=4.9786[\exp (0.000212 Z)]$ fitted to data presented by Shaffer (1996). Values for $b$ are probably not constant over the ocean. Analyzing data from 17 field experiments, Berelson (2001) found $b$ to range between -0.6 and -1.28 , and a positive correlation of $-b$ with $E P_{C}$. A range of -0.6 to -1.3 is adopted here for estimating the dependence of $e_{\mathrm{C}: \mathrm{N}}{ }^{\text {req }}$ and $b$.

A realistic description of $\mathrm{POC}$ fluxes including carbon associated with TEP will probably be somewhere between the 2 models used in this study, since some TEP will always be included in the standard analysis of POC.

\section{RESULTS}

The depth distribution of the $\mathrm{C}: \mathrm{N}$ ratio of particle flux $\left(J_{\mathrm{C}: \mathrm{N}}\right)$ for standard experiments $\left(r_{\mathrm{C}: \mathrm{N}}=6.6\right)$ with Models 1 and 2 is shown in Figs. 2 \& 3, respectively. In both models, the modeled $\mathrm{C}: \mathrm{N}$ flux ratios increase with depth if $e_{\mathrm{C}: \mathrm{N}}$ is larger than $r_{\mathrm{C}: \mathrm{N}}$. Even for marginally elevated $e_{\mathrm{C}: \mathrm{N}}$ ratios, between 6.6 and 7, Model 1 predicts deep water $(4000 \mathrm{~m}) \mathrm{C}: \mathrm{N}$ ratios of sinking particles of 6.6 to 22 . For higher $e_{\mathrm{C}: \mathrm{N}}$ ratios (8 to 15$)$, the predicted $\mathrm{C}: \mathrm{N}$ ratios of sinking particles increase dramatically already in shallow water, particularly due to the rapid nitrogen depletion in sinking particles computed by the model (Fig. 2 insert). Model 2 predicts a more moderate increase in $\mathrm{C}: \mathrm{N}$ flux ratios since, 


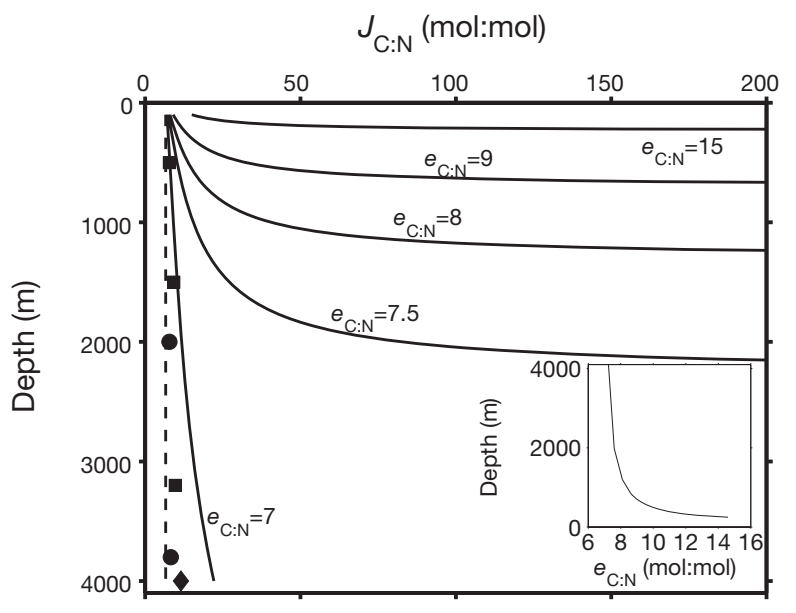

Fig. 2. The vertical distribution of the $\mathrm{C}: \mathrm{N}$ ratio of sinking particles $\left(J_{\mathrm{C}: \mathrm{N}}\right)$ for a set of given $\mathrm{C}: \mathrm{N}$ ratios of export production $\left(e_{\mathrm{C}: \mathrm{N}}\right)$ and a $\mathrm{C}: \mathrm{N}$ ratio of remineralisation of $r_{\mathrm{C}: \mathrm{N}}=6.6$ (constant over depth) as computed from Model 1. Selected C:N ratios of sinking particles observed with sediment traps are shown for comparison (匹: Conte et al. 2001; •: Honjo \& Manganini 1993; $\$$ : Martin et al. 1987, $4000 \mathrm{~m}$ value only). If $e_{\mathrm{C}: \mathrm{N}}$ is larger than $r_{\mathrm{C}: \mathrm{N}}$, nitrogen progressively depletes in the particle flux and eventually becomes zero. The model-predicted depth at which all nitrogen is remineralised is shown as a function of $e_{\mathrm{C}: \mathrm{N}}$ in the insert

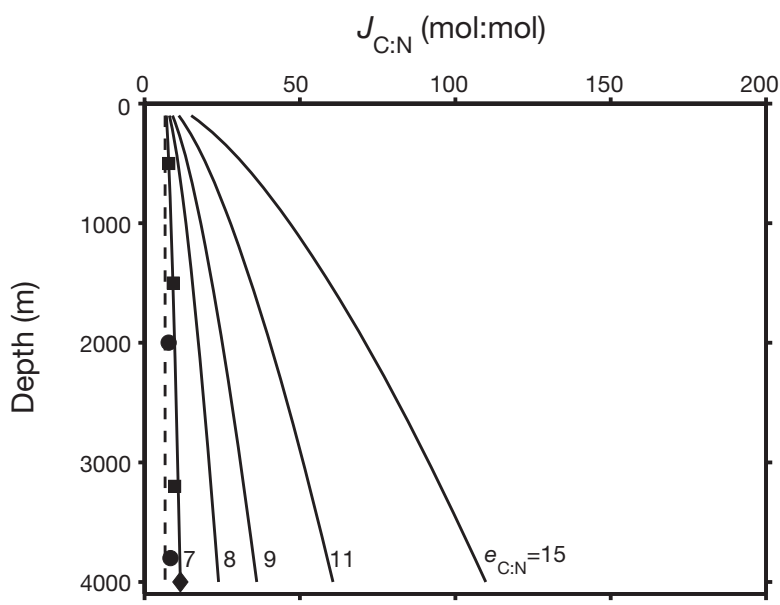

Fig. 3. The vertical distribution of $J_{\mathrm{C}: \mathrm{N}}$ for a set of given $e_{\mathrm{C}: \mathrm{N}}$ ratios and $r_{\mathrm{C}: \mathrm{N}}=6.6$ as computed with Model 2. Selected C:N ratios of sinking particles observed with sediment traps are shown for comparison (匹: Conte et al. 2001; •: Honjo \& Manganini 1993; : Martin et al. 1987, 4000 m value only)

according to the model assumptions, nitrogen never depletes. Still, the increase of $J_{\mathrm{C}: \mathrm{N}}$ between 100 and $4000 \mathrm{~m}$ ranges from 1.6 -fold $\left(e_{\mathrm{C}: \mathrm{N}}=7\right)$ to 7.3 -fold $\left(e_{\mathrm{C}: \mathrm{N}}=15\right)$. Both models behave very similarly compared with the data analysis of the POM decompositions experiment (Fig. 1, Verity et al. 2000). Small differences between $e_{\mathrm{C}: \mathrm{N}}$ and $r_{\mathrm{C}: \mathrm{N}}$ are sufficient to yield large $\mathrm{C}: \mathrm{N}$ ratios of residual POM.
How does this compare with observed $\mathrm{C}: \mathrm{N}$ flux ratios in the deep ocean? Observations with particle interceptor traps usually revealed higher than Redfield C:N ratios and also a slight trend (increase) with depth (Schneider et al. 2003). Mean annual flux ratios from a 9 yr time series observation at the OFP/BATS (Ocean Flux Program, Bermuda Atlantic Time Series, Conte et al. 2001) station increase from $7.8 \pm 1.4(500 \mathrm{~m})$ to $9.2 \pm$ $1.5(1500 \mathrm{~m})$ and $9.7 \pm 1.4(3200 \mathrm{~m})$. Similar increases are seen at other sites in the North Atlantic. Honjo \& Manganini (1993), for example, report annual C:N ratios of 7.8 to 8.3 between 2000 and $3800 \mathrm{~m}$ at $47^{\circ} \mathrm{N}$, $20^{\circ} \mathrm{W}$. Data compiled by Antia et al. (2001) from the Atlantic Ocean $(n=45)$ show a mean annual C:N flux ratio of $8.8 \pm 1.7$ and a small increase with depth (not shown). For the standard parameters $\left(b=-0.68, r_{\mathrm{C}: \mathrm{N}}\right.$ $=6.6$ ), the observed deep water C:N flux ratios of Honjo \& Manganini (1993), Conte et al. (2001) and Martin et al. (1987) (11.5 at $4000 \mathrm{~m}$ ) are reproduced by Model 1 for $e_{\mathrm{C}: \mathrm{N}}{ }^{\text {req }}$ values between 6.7 and 6.85 (Fig. 4). For Model 2, the solutions for $e_{\mathrm{C}: \mathrm{N}}^{\text {req }}$ range from 6.8 to 7.0. The respective excess carbon fraction to carbon export production ranges between 1.8 and $3.6 \%$ (Model 1), and 2.4 and 6.1\% (Model 2).

Using lower $b$-values in the models requires lower $e_{\mathrm{C}: \mathrm{N}}$ input values to compute observed deep sea C:N flux ratios (Fig. 5). If a value of $b=-1$ (Koeve 2002) is assumed, the excess carbon export required to match the deep water C:N flux ratios is between 1 and $2 \%$ of the Redfield equivalent carbon export (open symbols in Fig. 4). Overall, the effect of $b$ on $e_{\mathrm{C}: \mathrm{N}}{ }^{\text {req }}$ is moderate (Fig. 5 ).

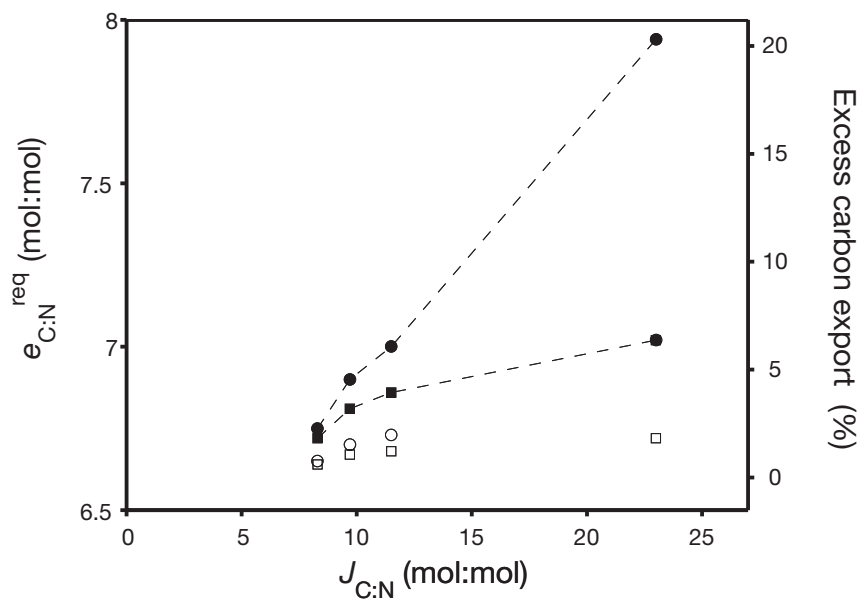

Fig. 4. Estimates of $e_{\mathrm{C}: \mathrm{N}}{ }^{\text {req }}$ (mol:mol), the C:N ratio of export production required to sustain observed deep water C:N ratios of sinking particles $\left(J_{\mathrm{C}: \mathrm{N}}\right)$, and the related excess carbon export (\%) as a function of $J_{\mathrm{C}: \mathrm{N}}$. All model runs assume that the $\mathrm{C}: \mathrm{N}$ ratio of remineralisation is constant over depth $\left(r_{\mathrm{C}: \mathrm{N}}=6.6\right)$. Open symbols: $b=-1$; Closed symbols: $b=$ -0.68 ; $\square, \square$ : Model 1; O, $\bullet$ : Model 2. $b$ is the $Z$-exponent of the $J$-EP-Z curve (Eq. 1) 


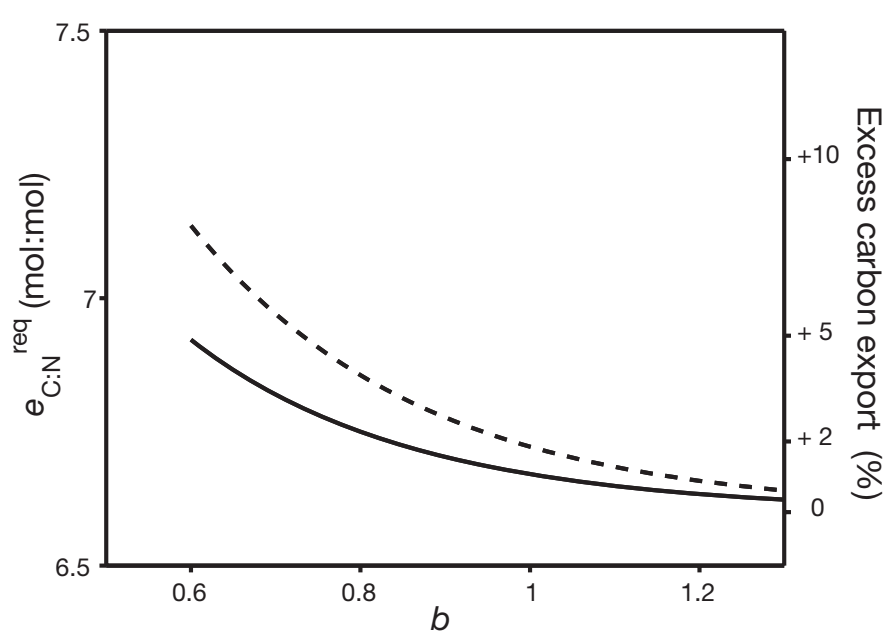

Fig. 5. Estimates of $e_{\mathrm{C}: \mathrm{N}}{ }^{\text {req }}$ (mol:mol) and excess carbon export $(\%)$ as a function of the $Z$-exponent $b$ of the $J$-EP- $Z$ function (Eq. 1). Solid line: Model 1; dashed line: Model 2. Computations are carried out for standard conditions assuming $r_{\mathrm{C}: \mathrm{N}}=$ 6.6 and $J_{\mathrm{C}: \mathrm{N}}=11.5$ at $4000 \mathrm{~m}$ depth

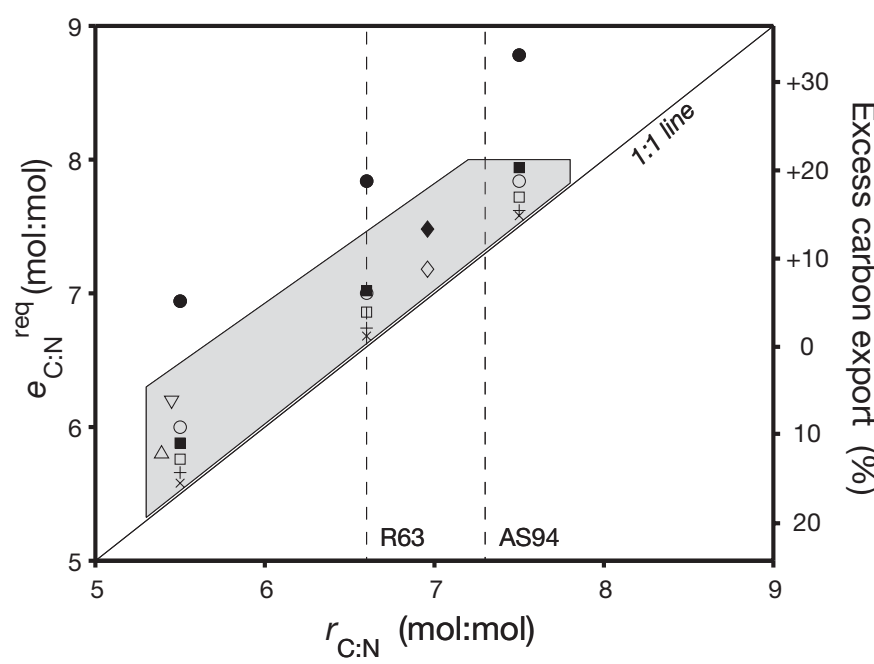

Fig. 6. Estimates of $e_{\mathrm{C}: \mathrm{N}}{ }^{\text {req }}$ (mol:mol) and excess carbon export $(\%)$ as a function of the $\mathrm{C}: \mathrm{N}$ remineralisation ratio $\left(r_{\mathrm{C}: \mathrm{N}}\right)$. Open symbols: C:N ratio of sinking particles of 11.5 at $4000 \mathrm{~m}$ depth is prescribed (Martin et al. 1987). Closed symbols: C:N ratio of sinking particles is set to 23 at $4000 \mathrm{~m}$ depth. Model runs with depth invariable $r_{\mathrm{C}: \mathrm{N}}$ values are as follows: $\square, \mathbf{\square}$ : Model $1, b=$ -0.68 ; O, : Model 2, $b=-0.68$; $\times$ : Model 1, $b=-1$; +: Model 2, $b=-1$. Model runs with $r_{\mathrm{C}: \mathrm{N}}$ values which increase over depth are as follows: $\diamond \diamond$ : after Martin et al. (1987); triangles: after Shaffer (1996); $\Delta$ : Model 1; $\nabla$ : Model 2. Dashed lines indicate remineralisation $\mathrm{C}: \mathrm{N}$ ratios suggested by Redfield et al. (1963), R63, and Anderson \& Sarmiento (1994), AS94. Shaded area indicates the likely range of excess carbon export (for details see 'Discussion')

Experiments with a range of $r_{\mathrm{C}: \mathrm{N}}$ values between 5.5 and 7.5, but constant over depth (Fig. 6), show that it is mainly the $r_{\mathrm{C}: \mathrm{N}}$ ratio which determines $e_{\mathrm{C}: \mathrm{N}}{ }^{\text {req }}$. $e_{\mathrm{C}: \mathrm{N}}{ }^{\text {req }}$ scales to $r_{\mathrm{C}: \mathrm{N}}$ close to a 1:1 relationship. Differences of $e_{\mathrm{C}: \mathrm{N}}^{\text {req }}$ between different models or the effect of vari- able Z-exponents are small compared to differences related to uncertainties of $r_{\mathrm{C}: \mathrm{N}}$. A depth-dependent distribution of $r_{\mathrm{C}: \mathrm{N}}$ has been suggested among others by Martin et al. (1987) and Shaffer (1996). Using such depth profiles of $r_{\mathrm{C}: \mathrm{N}}$ here yields $e_{\mathrm{C}: \mathrm{N}}{ }^{\text {req }}$ of 7.18 and of 5.8 to 6.2 for the Martin et al. (1987) and Shaffer (1996) equations, respectively, to match a deep water $J_{\mathrm{C}: \mathrm{N}}$ of 11.5 at $4000 \mathrm{~m}$ (Fig. 6).

Finally, an extreme assumption is made to reflect the possibility that TEP-associated carbon is severely underestimated in deep traps. Here, I assume that the $\mathrm{C}: \mathrm{N}$ flux ratio at $4000 \mathrm{~m}$ is 23 (2 times the value measured by Martin et al. 1987 in their deep traps). Depending on the model assumptions, between 3 (Model 1, $b=-1$ ) and $21 \%$ (Model 2, $b=-0.68$ ) excess carbon export is required to yield such high deep water $\mathrm{C}: \mathrm{N}$ ratios $\left(r_{\mathrm{C}: \mathrm{N}}=6.6\right.$, Fig. 4). Note the strong difference between the functional response of $e_{\mathrm{C}: \mathrm{N}}$ req over $J_{\mathrm{C}: \mathrm{N}}$ for Models 1 and 2.

\section{DISCUSSION}

Results from this study revealed that an excess particulate carbon export from the euphotic zone, for example in the form of TEP, of only 1 to $6.1 \%$ of the Redfield equivalent carbon export is required to reproduce the observed $J_{\mathrm{C}: \mathrm{N}}$ of sinking particles in the deep ocean (8.3 to 11.5), when a remineralisation ratio of 6.6 (Redfield et al. 1963) is assumed (Fig. 4). A higher excess export demands that either (1) the deep ocean $\mathrm{C}: \mathrm{N}$ flux ratio or (2) the Z-exponent of particle flux have been severely underestimated, or that (3) the C:N remineralisation ratio due to particles is much higher. In the following sections I discuss these 3 aspects separately.

\section{Uncertainties of observed C: $\mathrm{N}$ flux ratios}

The estimation of the C:N flux ratio of particles sampled with sediment traps is prone to a number of uncertainties. For example, zooplankton, which is known to actively enter traps ('swimmers'), may add organic matter with a low $\mathrm{C}: \mathrm{N}$ ratio (5 to 6) and dilute the signal of sinking POM. Picking swimmers prior to POM measurements, a standard procedure of trap sample handling, would partly prevent this artifact; however, elevated concentrations of DOM have been found to accumulate in sample cups of sediment traps (Kähler \& Bauerfeind 2001), originating from the dissolution of sinking particles, but likewise from swimmers. Kähler \& Bauerfeind (2001) found an apparent C:N ratio of sinking particles, estimated from POC and PON analysis of trap samples, of 9.6 (annual integral) in a shallow (135 m) trap de- 
ployed in the Greenland Sea. Significant concentrations of DOM with a low $\mathrm{C}: \mathrm{N}$ ratio were measured in the supernatant of the trap cup. Including the DOC and DON fractions, which Kähler \& Bauerfeind (2001) could assign to the passive particle flux, yielded a corrected C:N ratio of 3.8 (annual integral). Recognising that lipids may occasionally be completely lost from sediment traps (Kähler \& Bauerfeind 2001) and assuming a lipid contribution to total plankton carbon of $22 \%$ (computed after Hedges et al. 2002), requires an upward correction and yields an annually integrated C:N ratio of $(<) 4.8$. Obviously, the DOM corrected estimate of the C:N ratio of the passive flux of organic carbon entering the trap of 3.8 to 4.8 is very different from the original POC:PON based estimate of 9.6.

If the results of the study of Kähler \& Bauerfeind (2001) apply in general to shallow traps, it causes doubt concerning elevated $\mathrm{C}: \mathrm{N}$ ratios frequently reported from shallow drifting sediment traps (e.g. Anderson \& Pondaven 2003) and as summarised in Schneider (2003) and Schneider et al. (2003). Fortunately, both the swimmer and the DOM problem show a depth-dependence (e.g. Michaels et al. 1990, P. Kähler \& IfM-Kiel pers. comm.), indicating that deep traps are much less affected (Honjo et al. 1995). Similarly, deep traps are also much less prone to hydrodynamic biases and trapping efficiency problems (Scholten et al. 2001, Yu et al. 2001) which add to the uncertainties of $\mathrm{C}: \mathrm{N}$ flux ratios in shallow traps. Hence, I restricted myself to the use of data from deep traps as a constraint in the model experiments.

A problem, which may call the reliability of C:N flux ratios from deep traps into question, is whether TEPassociated carbon is fully included in the POC measurement of material from sediment traps. POM is conventionally filtered on glass fiber filters (Ehrhard \& Koeve 1999), 'depth filters' consisting of a matrix of glass fiber structures, which have a nominal pore size of $0.7 \mu \mathrm{m}$ (Whatman GF/F filters). Though the effective pore size may decrease due to clogging over filtration time, it is possible that small particles (e.g. bacteria, viruses, TEP) are not retained quantitatively and hence, are not fully included in POC analysis. Using size-fractionated filtration, Passow \& Alldredge (1995) observed that about 60 to $70 \%$ of TEP were lost when $0.6 \mu \mathrm{m}$ membrane filters were used instead of $0.2 \mu \mathrm{m}$ membrane filters. Pre-combusted glass fiber filters, however, may behave differently. Morán et al. (1999), for example, showed that glass fiber filters adsorb significant amounts of ${ }^{14} \mathrm{C}$-labeled freshly produced dissolved organic matter. I speculate that this may also apply to surface-reactive TEP and that TEP is more efficiently retained on GF/F filters compared to membrane filters of similar pore size.

As yet, little is known about the flux of TEP and TEPassociated carbon into the deep sea. A study from the
Santa Barbara Channel off California suggests that the ratio of deep $(500 \mathrm{~m})$ flux to surface standing stock in the surface layer is similar for POC and TEP (about 1 to $2 \% \mathrm{~d}^{-1}$ each) (Passow et al. 2001), indicating that Model 1 is more applicable. During that 2 yr study, the integrated overall TEP to POC ratio (roughly estimated from their Fig. 3) was about $0.5 \mathrm{mg}$ Xanthan:mg POC. Combining these data with the carbon to TEP conversion relationship found for TEP produced from diatom cultures (Engel \& Passow 2001), yields a ratio of about 0.4 (TEP-carbon:POC). Using this first order estimate, one may conclude that TEP-carbon either made up about $40 \%$ of the observed POC flux (compliant with the assumptions of Model 1) or that the true POC flux and the $\mathrm{C}: \mathrm{N}$ flux ratio were underestimated by about $30 \%$ (compliant with the assumptions of Model 2) in the study of Passow et al. (2001). Model computation assuming a deep ocean $J_{\mathrm{C}: \mathrm{N}}$ of 23 (2 times the observed $4000 \mathrm{~m}$ value of Martin et al. 1987) is equivalent to assuming true carbon fluxes to be underestimated by $100 \%$ due to unrecognised TEP, which is well beyond the upper bound estimate ( $30 \%$ underestimation) based on Passow et al. (2001). Hence, $2 \times J_{\mathrm{C}: \mathrm{N}}$ experiments are not included in the envelop of the likely range of excess carbon export (shaded patch in Fig. 6).

Given the problems of trapping efficiency, POM dissolution in traps, swimmers and TEP-carbon analytics discussed above, is there independent evidence for the $\mathrm{C}: \mathrm{N}$ ratio of sinking particles in the deep ocean? Samples of 'fluff', detritus on the sea floor, may provide such evidence. Such material has been observed to arrive within a few weeks after the surface ocean spring bloom in the deep sea (Billett et al. 1983) and has been sampled by multicorers or from submarines. Beaulieu (2002) reviews fluff observations and the chemical composition of the material. $\mathrm{C}: \mathrm{N}$ ratios range from 6 to 24, with most of the observations having C:N ratios of lower than 12 . The high end ones, partially originating from thin surface layers of the sediment (Smith et al. 1998, their Table 4), probably include older material, which has already been reworked in the sediments and, therefore, has a high $\mathrm{C}: \mathrm{N}$ ratio. This is supported by the carbon-14 age of fluff (Druffel et al. 1998) being much more similar to sediment carbon-14 ages than to those from suspended or sinking POC, or from surface ocean DIC.

\section{Effect of $b$ on $e_{\mathrm{C}: \mathrm{N}}{ }^{\text {req }}$}

A range of values of the $Z$-exponents of the $J$-EP- $Z$ curve from -0.6 to -1.3 was tested (Fig. 5). Low end values $(b=-1.28)$, estimated by Berelson (2001) for spring bloom conditions in the temperate North Atlantic, require carbon export to be about $5 \%$ (Model 1) 
to $7 \%$ (Model 2) lower compared with high end $b$-values $(b=-0.6)$ to sustain observed deep ocean $J_{\mathrm{C}: \mathrm{N}}$ values. Berelson (2001) suggests that low $b$-values correspond to regimes of higher export production $\left(E P_{\mathrm{C}}\right)$ and it may be that the regional distribution of deep water $J_{\mathrm{C}: \mathrm{N}}$ reflects the variability in $b$. This, however, is difficult to test since estimates of $r_{\mathrm{C}: \mathrm{N}}$ (see next section) usually average over large horizontal distances. One may speculate that oligotrophic regions have higher $e_{\mathrm{C}: \mathrm{N}}^{\text {req }}$ than eutropic regimes. The overall effect of the $Z$-exponent of the $J-E P-Z$ curve on $e_{\mathrm{C}: \mathrm{N}}{ }^{\text {req }}$, however, is small compared with the effect of $r_{\mathrm{C}: \mathrm{N}}$ (Figs. $5 \& 6$ ). The remaining discussion, therefore, focuses on a brief review of $r_{\mathrm{C}: \mathrm{N}}$, its vertical distribution and the possible impact of DOM remineralisation on $r_{\mathrm{C}: \mathrm{N}}$.

\section{$\mathrm{C}: \mathrm{N}$ ratios of remineralisation in the interior of the ocean}

The elemental ratios of remineralisation in the interior of the ocean have been estimated repeatedly from the change of total $\mathrm{CO}_{2}, \mathrm{NO}_{3}, \mathrm{PO}_{4}$ and $\mathrm{O}_{2}$ along isopycnals or on neutral surfaces. This method requires that the remineralisation signal is separated from changes in the tracer distribution due to hydrodynamic processes such as isopycnal and diapycnal mixing, and from effects due to denitrification and the invasion of anthropogenic $\mathrm{CO}_{2}$. Most estimates of the mean ocean $\mathrm{C}: \mathrm{N}$ remineralisation ratio range between $5.6 \pm 0.5$ (Takahashi et al. 1985) and $7.3 \pm 1.3$ (Anderson \& Sarmiento 1994). Evidence for vertical variations of these ratios is controversial. Several authors found no significant trend over depth (Broecker et al. 1985, Takahashi et al. 1985), in particular, when effects due to denitrification (Anderson \& Sarmiento 1994) or from the time history of the invasion of anthropogenic $\mathrm{CO}_{2}$ (Körtzinger et al. 2001b) have been corrected for. Other studies, on the contrary, found an increase over depth from shallow water $\mathrm{C}: \mathrm{N}$ remineralisation ratios of $5.1(100 \mathrm{~m})$ to $9.4(3000 \mathrm{~m})$ (Shaffer 1996) and from $4.5 \pm 0.3\left(\rho<1027.7 \mathrm{~kg} \mathrm{~m}^{-3}\right)$ to $11.0 \pm 0.5(\rho>1027.7 \mathrm{~kg}$ $\mathrm{m}^{-3}$ ) in the subarctic North Atlantic (Thomas 2002). A similar increase of $\mathrm{C}: \mathrm{N}$ remineralisation ratios with depth has been inferred from the VERTEX particle flux data set (Martin et al. 1987).

The range of $r_{\mathrm{C}: \mathrm{N}}$ used in this study is in good agreement with $r_{\mathrm{C}: \mathrm{N}}$ estimates based on decomposition experiments of phytoplankton-derived POM (Verity et al. 2000; Fig. 1). The mean $r_{\mathrm{C}: \mathrm{N}}( \pm \mathrm{SD})$ from both experiments is $5.4 \pm 1.6(\mathrm{n}=6)$ and the standard deviation reduces to 0.5 , if one only uses data from the time period of rapid POM change over time $(n=4)$. If these biological estimates of $r_{\mathrm{C}: \mathrm{N}}$ reflect POM degradation in the ocean more accurately than those from isopycnal analysis (see discussion on effects of DOM remineralisation on $r_{\mathrm{C}: \mathrm{N}}$, below), they clearly point towards low excess carbon export into the deep sea (Fig. 6).

The spread of $r_{\mathrm{C}: \mathrm{N}}$ values has been implemented in the sensitivity computations of this study. Constant $r_{\mathrm{C}: \mathrm{N}}$ values between 5.5 and 7.5 require $e_{\mathrm{C}: \mathrm{N}}{ }^{\text {req }}$ ratios of 5.76 and 7.72 to sustain a deep ocean C:N flux ratio of 11.5 . Hence, $r_{\mathrm{C}: \mathrm{N}}$ shows up to be the most significant determinant of the $e_{\mathrm{C}: \mathrm{N}}{ }^{\text {req }}$ to deep C:N flux relationship.

Moreover, the shallow and intermediate water $r_{\mathrm{C}: \mathrm{N}}$ largely determines the $e_{\mathrm{C}: \mathrm{N}}{ }^{\text {req }}$ due to the predominance of shallow waters for remineralisation. This is evident from experiments with depth variable $r_{\mathrm{C:N}}$ values. Adopting the $r_{\mathrm{C}: \mathrm{N}}$ vertical distribution found by Shaffer (1996) yields $e_{\mathrm{C}: \mathrm{N}}{ }^{\text {req }}$ of 5.8 (Model 1) and 6.2 (Model 2) to sustain the deep water $\mathrm{C}: \mathrm{N}$ flux ratio of $11.5(b=$ -0.68). Depth integrated $r_{\mathrm{C}: \mathrm{N}}$ from these experiments are 5.4 and 5.5, respectively, and are very close to the $r_{\mathrm{C}: \mathrm{N}}$ ratio of 5.1 at a depth of $100 \mathrm{~m}$ (Shaffer 1996). The same is seen from the experiment with the $r_{\mathrm{C}: \mathrm{N}}$ distribution adopted from Martin et al. (1987). Here, the $100 \mathrm{~m}$ value is 6.2 , the depth integrated $r_{\mathrm{C}: \mathrm{N}}$ is 7.0 , and $e_{\mathrm{C}: \mathrm{N}}^{\text {req }}$ is 7.18 . Elevated deep water values of $r_{\mathrm{C}: \mathrm{N}}$ had little impact on $e_{\mathrm{C}: \mathrm{N}}{ }^{\text {req }}$.

So far, the $r_{\mathrm{C}: \mathrm{N}}$ ratio was used irrespective of whether it is due to the remineralisation of particulate or dissolved matter. In the deep ocean, almost $100 \%$ of remineralisation is due to particles, since the change of DOC (Hansell \& Carlson 1998) along the deep water path of the conveyor belt is very small compared with the concomitant increase in total $\mathrm{CO}_{2}$. On shallow isopycnals, however, DOM may contribute significantly to carbon remineralisation. Doval \& Hansell (2000), for example report that remineralisation of DOC may account for up to $50 \%$ of apparent oxygen utilisation on shallow isopycnals of the subtropical thermocline in the South Pacific. No concurrent DON measurements are available from that study and hence, little is known about the $\mathrm{C}: \mathrm{N}$ remineralisation ratio of DOM on these shallow isopycnals. If the latter remineralisation ratio is elevated similarly to the $C: N$ ratio of seasonally accumulating DOM in the North Atlantic (Williams 1995, Kähler \& Koeve 2001), the overall upper ocean $r_{\mathrm{C}: \mathrm{N}}$ ratios may overestimate the remineralisation ratios related to the remineralisation of sinking particles.

\section{Implications}

Carbon export in excess of the Redfield $(\mathrm{C}: \mathrm{N}=6.6)$ equivalent of nitrogen export production ranging from about -16 to about $21 \%$ have been estimated in this study to be sufficient to sustain observed elevated deep water $\mathrm{C}: \mathrm{N}$ ratios of sinking particles. Assuming 
that a considerable amount of carbon, for example in the form of TEP or carbon-rich DOM from particle dissolution in sample cups, has been overlooked analytically in deep sediment traps, yields an additional excess carbon export of between 3 (Model 1) and 15\% (Model 2). The median excess carbon export amounts to 3 ( $\mathrm{n}=16$, experiments with $2 \times J_{\mathrm{C}: \mathrm{N}}$ excluded) to $5.6 \%(\mathrm{n}=22$, all experiments). It is concluded that, in agreement with $\mathrm{C}: \mathrm{N}$ remineralisation ratios below the winter mixed layer, only a moderate fraction of carbon overconsumption is exported into the deep ocean.

This small amount of excess carbon export, or more specifically a C:N ratio of export production of particles which is a little larger than the depth integrated C:N ratio of remineralisation, is sufficient to explain elevated $\mathrm{C}: \mathrm{N}$ ratios of sinking particles in the deep ocean of 9 to 11.5 (and up to 23 for $2 \times J_{\mathrm{C}: \mathrm{N}}$ experiments) and its increase over depth. This holds irrespective of whether the remineralisation $\mathrm{C}: \mathrm{N}$ ratio is constant over depth or not. It is the preservation of a subtle amount of extra carbon in the export from the euphotic zone which becomes progressively significant during transit to depth when the flux of particulate organic matter rapidly decreases with depth, and particulate organic carbon and nitrogen are remineralised in a ratio close to that proposed by Redfield et al. (1963).

Evans \& Fasham (1993) showed that preferential remineralisation of nitrogen from sinking POM will cause a decrease in $\mathrm{CO}_{2}$ concentration in the surface ocean. Hence, what matters is the $\mathrm{C}: \mathrm{N}$ ratio at the reference depth of carbon sequestration, that is of carbon export on longer than annual time scales (Riebesell \& Wolf-Gladrow 1992). This reference depth is highly variable in the ocean. In temperate and higher latitude waters, it is the maximum depth of winter mixing; in upwelling regions, the lower boundary of the upwelling source water may be taken as such (Koeve 2002). For a brief estimate of the effect of preferential nitrogen remineralisation on the basin scale of the sequestration of organic carbon, I estimate the ratio of $J_{\mathrm{C}: \mathrm{N} \text { (sequ) }} / e_{\mathrm{C}: \mathrm{N}}$ from formulas given in Table 1 using average values for $Z_{\text {sequ }}$ for biogeographical provinces of the Atlantic ocean (Koeve 2002) and median values of $e_{\mathrm{C}: \mathrm{N}}(6.79), r_{\mathrm{C}: \mathrm{N}}(6.6)$ and $b(-1)$ from this study. Combining province means of $J_{\mathrm{C}: \mathrm{N}(\text { sequ })} / e_{\mathrm{C}: \mathrm{N}}$ with $J$-POC $\mathrm{POqu}_{\text {sequ }}$ (Koeve 2002) yields that preferential N-remineralisation is equivalent to 1 to $1.5 \%$ of the $J$-POC sequ without preferential $\mathrm{N}$-remineralisation. Looking at the basin scale difference between carbon export production and effective carbon flux at the base of the winter mixed layer, the effects of Redfield equivalent remineralisation within the seasonal thermocline or the effect of $\mathrm{CaCO}_{3}$ sequestration (Koeve 2002) are each about 10 times as large as the effect of preferential N-remineralistion.
Export of DOC from the euphotic zone during winter convection has been reported (Hansell \& Carlson 2001) and can account for the export of a fraction of seasonal net carbon uptake. In addition, a rapid transfer of carbon from the surface mixed layer during summer has been estimated from a carbon and nitrogen budget approach (Körtzinger et al. 2001a). Diapycnal transport is required for this summer time carbon export and TEP has been invoked as a possible vehicle for it (Körtzinger et al. 2001a). In that study, carbon overconsumption was not associated with the diatom spring bloom (Koeve 2004) but occurred later into the summer system. Slow sinking speeds of TEP-rich aggregates (Engel \& Schartau 1999) not ballasted with opal, calcium carbonate, or terrigeneous matter and grazing (Dilling et al. 1998, Prieto et al. 2001) or disruption of aggregates by large zooplankton (Dilling \& Alldredge 2000) may explain why such an export from the surface mixed layer during summer does not lead to an effective export of excess carbon into the deep sea.

The discrepancy between the range of $e_{\mathrm{C}: \mathrm{N}}{ }^{\text {req }}$ from this study and observed ranges of the $\mathrm{C}: \mathrm{N}$ ratio of net community production $\left(\mathrm{NCP}_{\mathrm{C}: \mathrm{N}}\right)$ may be interpreted as a measure of the coupling of total export production (POM + DOM route) and deep carbon fluxes. Since $e_{\mathrm{C}: \mathrm{N}}{ }^{\text {req }}$ (Figs. $4 \& 6$ ) was found to be much lower than recently published $\mathrm{NCP}_{\mathrm{C}: \mathrm{N}}$ values (10 to 15 , Sambrotto et al. 1993, Körtzinger et al. 2001a), I conclude that total export production and deep fluxes of carbon are only loosely coupled. A significant fraction of carbon overconsumption and its export from the euphotic zone may be related to a fraction of DOM poor in nitrogen (Williams 1995, Kähler \& Koeve 2001) which, however, appears to be remineralised in the upper ocean (Ono et al. 2001). As far as the sequestration of carbon into the deep ocean, for example below the winter mixed layer, is concerned, there is no need to involve a significant extra flux of carbon due to transparent exopolymer particles, as recently suggested by Engel \& Passow (2001) and Engel (2002).

Such a 'TEP-pump' appears, at least according to the results of this study, not to provide a significant mechanism to sequester carbon into the deep ocean in addition to the conventional Redfield biological pump, unless one can prove that either the remineralisation $\mathrm{C}: \mathrm{N}$ ratio $\left(r_{\mathrm{C}: \mathrm{N}}\right)$ or the $\mathrm{C}: \mathrm{N}$ ratio of sinking particles $\left(J_{\mathrm{C}: \mathrm{N}}\right)$ in the deep ocean are much larger than currently thought. For the computation of carbon fluxes into the deep ocean from $J$-EP- $Z$ functions, $E P_{\mathrm{C}}$ may be reliably, that is within the error bounds of other uncertainties inherent to this approach, computed from nutrientbased estimates of export production and a constant, Redfield, C:N:P ratio. 
Acknowledgements. A. Oschlies and P. Kähler (IfM-Kiel, Germany), H. Thomas (Royal NIOZ, The Netherlands) and 3 anonymous reviewers provided very helpful comments to an earlier version of this manuscript. P. Verity provided published original data. This is a contribution to the German Synthesis and Modelling Program of the Joint Global Ocean Flux Study (JGOFS). Funding by the German Ministry of Research (BMBF) to G. Wefer (MARUM, Bremen) and W.K. is acknowledged.

\section{LITERATURE CITED}

Alldredge A (1998) The carbon, nitrogen and mass content of marine snow as a function of aggregate size. Deep-Sea Res I 45:529-541

Alldredge AL, Passow U, Logan BE (1993) The abundance and significance of a class of large, transparent organic particles in the ocean. Deep-Sea Res I 40:1131-1140

Anderson LA, Sarmiento JL (1994) Redfield ratios of remineralization determined by nutrient data analysis. Global Biogeochem Cycles 8:65-80

Anderson TR, Pondaven P (2003) Non-redfield carbon and nitrogen cycling in the Sargasso Sea: pelagic imbalances and export flux. Deep-Sea Res I 50:573-591

Antia AN, Koeve W, Fischer G, Blanz T and 11 others (2001) Basin-wide particulate carbon flux in the Atlantic Ocean: regional export patterns and potential for atmospheric carbon sequestration. Global Biogeochem Cycles 15:845-862

Beaulieu S (2002) Accumulation and fate of phytodetritus on the sea floor. Oceanogr Mar Biol 40:171-232

Berelson WM (2001) The flux of particulate organic carbon into the ocean interior: a comparison of four U.S. JGOFS regional studies. Oceanography 14(4):59-67

Betzer PR, Showers WJ, Laws EA, Winn CD, DiTullio GR, Kroopnick PM (1984) Primary productivity and particle fluxes on a transect of the equator at $153^{\circ} \mathrm{W}$ in the Pacific Ocean. Deep Sea Res 31:1-11

Billet DSM, Lampitt RS, Rice AL, Mantoura RFC (1983) Seasonal sedimentation of phytoplankton to the deep sea benthos. Nature 302:520-522

Boyd PW, Stevens CL (2002) Modelling particle transformations and the downward organic carbon flux in the NE Atlantic Ocean. Prog Oceanogr 52:1-29

Broecker WS, Takahashi T, Takahashi T (1985) Sources and flow patterns of deep-ocean waters as deduced from potential temperature, salinity, and initial phosphate concentrations. J Geophys Res 90C:6925-6939

Buesseler KO (1991) Do upper-ocean sediment traps provide an accurate record of particle flux? Nature 353:420-423

Conte MH, Ralph N, Ross EH (2001) Seasonal and interannual variability in deep ocean particle flux at the Oceanic Flux Program (OFP)/Bermuda Atlantic Time Series (BATS) site in the western Sargasso Sea near Bermuda. Deep-Sea Res II 48: 1471-1505

Copin-Montégut C, Copin-Montégut G (1983) Stoichiometry of carbon, nitrogen, and phosphorus in marine particulate matter. Deep-Sea Res 30:31-46

Dilling L, Alldredge AL (2000) Fragmentation of marine snow by swimming macrozooplankton: a new process impacting carbon cycling in the sea. Deep-Sea Res I 47:1227-1245

Dilling L, Wilson J, Steinberg D, Alldredge AL (1998) Feeding by the euphausiid Euphausia pacifica and the copepod Calanus pacificus on marine snow. Mar Ecol Prog Ser 170:189-201

Doval MD, Hansell DA (2000) Organic carbon and apparent oxygen utilization in the western South Pacific and the central Indian Ocean. Mar Chem 68:249-264

Druffel ERM, Bauer JE, Williams PM, Griffin S, Wolgast D (1996)
Seasonal variability of particulate organic radiocarbon in the northeast Pacific Ocean. J Geophys Res 101:20543-20552

Druffel ERM, Griffin S, Honjo S, Manganini SJ (1998) Evidence of old carbon in the deep water column of the Panama Basin from natural radiocarbon measurements. Geophys Res Lett 25:1733-1736

Ehrhard MG, Koeve W (1999) Determination of particulate organic carbon and nitrogen. In: Grasshoff $\mathrm{K}$, Kremling $\mathrm{K}$, Ehrhardt MG (eds) Methods of seawater analysis, 3rd edn. Wiley-VCH, Weinheim, p 437-444

Engel A (2002) Direct relationship between $\mathrm{CO}_{2}$ uptake and transparent exopolymer particles production in natural phytoplankton. J Plankton Res 24:49-53

Engel A, Passow U (2001) Carbon and nitrogen content of transparent exopolymer particles (TEP) in relation to their Alcian Blue adsorption. Mar Ecol Prog Ser 219:1-10

Engel A, Schartau M (1999) Influence of transparent exopolymer particles (TEP) on sinking velocity of Nitzschia closterium aggregates. Mar Ecol Prog Ser 182:69-76

Evans GT, Fasham MJ (1993) Themes in modeling ocean biogeochemical processes. In: Evans GT, Fasham MJ (eds) Towards a model of ocean biogeochemical processes, Springer, Berlin, p 1-9

Gardner WD (2000) Sediment trap sampling in surface waters: issues and recommendations. In: Hanson RB, Ducklow HW, Field JG (eds) The changing ocean carbon cycle, a midterm synthesis of Joint Global Ocean Flux Study. International Geosphere-Biosphere Programme Book Series No. 5. Cambridge University Press, Cambridge, p 240-281

Gruber N, Sarmiento JL (1997) Global patterns of marine nitrogen fixation and denitrification. Global Biogeochem Cycles 11:235-266

Hansell DA, Carlson CA (1998) Deep-ocean gradients in the concentration of dissolved organic carbon. Nature 395: 263-266

Hansell DA, Carlson CA (2001) Biogeochemistry of total organic carbon and nitrogen in the Sargasso Sea: control by convective overturn. Deep-Sea Res II 48:1649-1667

Hansell DA, Bates NR, Olson DB (2004) Excess nitrate and nitrogen fixation in the North Atlantic Ocean. Mar Chem 84: 243-265

Hedges JI, Baldock JA, Gélinas Y, Lee C, Peterson ML, Wakeham SG (2002) The biogeochemical and elemental composition of marine plankton: a NMR perspective. Mar Chem 78: $47-63$

Honjo S, Manganini SJ (1993) Annual biogenic particle fluxes to the interior of the North Atlantic Ocean; studied at $34^{\circ} \mathrm{N}$ $21^{\circ} \mathrm{W}$ and $48^{\circ} \mathrm{N} 21^{\circ} \mathrm{W}$. Deep-Sea Res II 40:587-608

Honjo S, Dymond J, Collier R, Manganini SJ (1995) Export production of particles to the interior of the equatorial Pacific Ocean during the 1992 EqPac experiment. Deep-Sea Res II 42:831-870

Kähler P, Bauerfeind E (2001) Organic particles in a shallow sediment trap: substantial loss to the dissolved phase. Limnol Oceanogr 46:719-723

Kähler P, Koeve W (2001) Marine dissolved organic matter: can its $\mathrm{C} / \mathrm{N}$ ratio explain carbon overconsumption? Deep-Sea Res I $48: 49-62$

Karl DM, Knauer GA (1989) Swimmers: a recapitulation of the problem and a potential solution. Oceanography 2:32-35

Koeve W (2001) Wintertime nutrients in the North Atlanticnew approaches and implications for estimates of seasonal new production. Mar Chem 74:245-260

Koeve W (2002) Upper ocean carbon fluxes in the Atlantic Ocean - the importance of the POC:PIC ratio. Global Biogeochem Cycles 16:1-17, 1056, doi: 10.1029/2001GB001836

Koeve W (2004) Spring bloom carbon to nitrogen ratio of net com- 
munity production in the temperate N. Atlantic. Deep-Sea Res I 51:1579-1600

Körtzinger A, Koeve W, Kähler P, Mintrop L (2001a) C:N ratios in the mixed layer during the productive season in the northeast Atlantic ocean. Deep-Sea Res I 48:661-688

Körtzinger A, Hedges JI, Quay PD (2001b) Redfield ratios revisited - removing the biasing effect of anthropogenic $\mathrm{CO}_{2}$. Limnol Oceanogr 46:964-970

Lampitt RS, Bett BJ, Kiriakoulakis K, Popova EE, Ragueneau O, Vangriesheim A, Wolff GA (2001) Material supply to the abyssal seafloor in the Northeast Atlantic. Prog Oceanogr 50: $27-63$

Lee C, Cronin C (1984) Particulate amino acids in the sea: effects of primary productivity and biological decomposition. J Mar Res 42:1075-1097

Mari X, Beauvais S, Lemee R, Pedrotti M (2001) Non-Redfield C:N ratio of transparent exopolymeric particles in the northwestern Mediterranean Sea. Limnol Oceanogr 46:1831-1836

Martin JH, Knauer GA, Karl DM, Broenkow WW (1987) VERTEX: carbon cycling in the northeast Pacific. Deep-Sea Res $34: 267-285$

McDougall TJ (1987) Neutral surfaces. J Phys Res 17:1950-1964

Michaels AF, Silver MW, Gowing MM, Knauer GA (1990) Cryptic zooplankton swimmers in upper ocean sediment traps. Deep Sea Res 37:1285-1296

Morán XAG, Gasol JM, Aurin MM, Estrada M (1999) A comparison between glass fibre and membrane filters for the estimation of phytoplankton POC and DOC production. Mar Ecol Prog Ser 187:31-41

Ono S, Ennyu A, Najjar RG, Bates NR (2001) Shallow remineralization in the Sargasso Sea estimated from seasonal variations in oxygen, dissolved inorganic carbon and nitrogen. Deep-Sea Res II 48:1567-1582

Passow U (2002) Transparent exopolymer particles (TEP) in aquatic environments. Prog Oceanogr. 55:287-333

Passow U (2004) Switching perspectives: do mineral fluxes determine particulate organic carbon fluxes or vice versa? Geochem Geophys Geosyst 5:Q04002, doi:10.1029/ 2003GC000670

Passow U, Alldredge AL (1995) A dye-binding assay for the spectrophotometric measurement of transparent exopolymer particles (TEP) in the ocean. Limnol Oceanogr 40:1326-1335

Passow U, Shipe R, Murray A, Pak D, Brzezinski M, Alldredge A (2001) The origin of transparent exopolymer particles (TEP) and their role in the sedimentation of particulate matter. Cont Shelf Res 21:327-346

Ploug H, Grossart HP (2000) Bacterial growth and grazing on diatom aggregates: respiratory carbon turnover as a function of aggregate size and sinking velocity. Limnol Oceanogr 45: $1467-1475$

Ploug H, Grossart H, Azam F, Jørgensen B (1999) Photosynthesis, respiration, and carbon turnover in sinking marine snow from surface waters of Southern California Bight: implications for the carbon cycle in the ocean. Mar Ecol Prog Ser 179:1-11

Prieto L, Sommer F, Stibor H, Koeve W (2001) Effects of planktonic copepods on transparent exopolymeric particles (TEP) abundance and size spectra. J Plankton Res 23:515-525

Redfield AC, Ketchum BH, Richards FA (1963) The influence of organisms on the composition of seawater. In: Hill MN (ed) The sea, Vol 2. John Wiley \& Sons, New York, p 26-77

Riebesell U, Wolf-Gladrow DA (1992) The relationship between physical aggregation of phytoplankton and particle flux: a numerical model. Deep-Sea Res 39:1085-1102

Sambrotto RN, Savidge G, Robinson C, Boyd P and 6 others (1993) Elevated consumption of carbon relative to nitrogen in the surface ocean. Nature 363:248-250

Schlitzer R (2000) Applying the adjoint method for biogeo- chemical modeling: export of particulate organic matter in the world ocean. Geophys Monogr 114:107-124

Schlitzer R (2002) Carbon export fluxes in the Southern Ocean: results from inverse modeling and comparison with satellitebased results. Deep-Sea Res I 49:1623-1644

Schneider B (2003) Variable C:N ratios of particulate organic matter and their influence on the marine carbon cycle. Rep Polar Mar Res 437:1-98

Schneider B, Schlitzer R, Fischer G, Nöthig EM (2003) Depthdependent elemental compositions of particulate organic matter (POM) in the ocean. Global Biogeochem Cycles 17: 1032, doi:10.1029/2002GB001871

Scholten JC, Fietzke J, Vogler S, Rutgers van der Loeff M and 6 others (2001) Trapping efficiency of sediment traps from the deep eastern North Atlantic: the ${ }^{230} \mathrm{Th}$ calibration. Deep-Sea Res II 48:2383-2408

Shaffer G (1996) Biogeochemical cycling in the global ocean. 2. New production, Redfield ratios, and remineralization in the organic pump. J Geophys Res 101C:3723-3745

Smith DC, Simon M, Alldredge AL, Azam F (1992) Intense hydrolytic enzyme activity on marine aggregates and implications for rapid particle dissolution. Nature 359:139-142

Smith KLJ, Baldwin RJ, Glatts RC, Kaufmann RS, Fisher EC (1998) Detrital aggregates on the sea floor: chemical composition and aerobic decomposition rates at a time-series station in the abyssal NE Pacific. Deep-Sea Res II 45:843-880

Suess E (1980) Particulate organic carbon flux in the ocean - surface productivity and oxygen utilization. Nature 288:260-263

Takahashi T, Broecker WS, Langer S (1985) Redfield ratio based on chemical data from isopycnal surfaces. J Geophys Res 90C:6907-6924

Thomas H (2002) Remineralisation ratios of carbon, nutrients, and oxygen in the North Atlantic Ocean: a field databased assessment. Global Biogeochem Cycles 16:1051, doi: 10.1029/2001GB001452

Thomas H, Ittekkot V, Osterroht C, Schneider B (1999) Preferential recycling of nutrients - the ocean's way to increase new production and to pass nutrient limitation. Limnol Oceanogr 44:1999-2004

Toggweiler JR (1993) Carbon overconsumption. Nature 363: 210-211

von Bodungen B, Wunsch M, Fürderer H (1991) Sampling and analysis of suspended and sinking particles in the Northern North Atlantic. Geophys Monogr 63:47-56

Verity PG, Williams SC, Hong Y (2000) Formation, degradation, and mass:volume ratios of detritus derived from decaying phytoplankton. Mar Ecol Prog Ser 207:53-68

Wakeham SG, Lee C, Farrington JW, Gagosian RB (1984) Biogeochemistry of particulate organic matter in the oceans: results from sediment trap experiments. Deep-Sea Res 31: $509-528$

Walsh ID, Gardner WD (1992) A comparison of aggregate profiles with sediment trap fluxes. Deep-Sea Res 39:1817-1834

Williams PJleB (1995) Evidence for the seasonal accumulation of carbon-rich dissolved organic material, its scale in comparison with changes in particulate material and the consequential effect on net C/N assimilation ratios. Mar Chem 51:17-29

Williams RG, Follows MJ (1998) The Ekman transfer of nutrients and maintenance of new production over the North Atlantic. Deep-Sea Res I 45:461-489

Yu E-F, Francois R, Bacon MP, Honjo S, Fleer AP, Manganini SJ, Rutgers van der Loeff MM, Ittekot V (2001) Trapping efficiency of bottom-tethered sediment traps estimated from the intercepted fluxes of ${ }^{230} \mathrm{Th}$ and ${ }^{231} \mathrm{~Pa}$. Deep-Sea Res I 48:864-889

Zeitzschel B, Diekmann P, Uhlmann L (1978) A new multisample sediment trap. Mar Biol 45:285-288

Submitted: December 12, 2002; Accepted: October 29, 2004

Proofs received from author(s): March 23, 2005 